\title{
Replacing Fallow with Cover Crops in a Semiarid Soil: Effects on Soil Properties
}

Humberto Blanco-Canqui*

University of Nebraska-Lincoln

Agronomy \& Horticulture

261 Plant Science Hall

Lincoln, NE 68583

John D. Holman

Kansas State Univ.

Southwest Research-Extension Center Garden City, KS 67846

Alan J. Schlegel

Kansas State Univ.

Southwest Research-Extension Center

Tribune, KS 67879

\section{John Tatarko}

USDA-ARS

Engineering \& Wind Erosion

Research Unit

Manhattan, KS 66502

Tim M. Shaver

University of Nebraska

West Central Research \&

Extension Center

North Platte, NE 69101
Replacement of fallow in crop-fallow systems with cover crops (CCs) may improve soil properties. We assessed whether replacing fallow in no-till winter wheat (Triticum aestivum L.)-fallow with winter and spring CCs for $5 \mathrm{yr}$ reduced wind and water erosion, increased soil organic carbon (SOC), and improved soil physical properties on a Ulysses silt loam (fine-silty, mixed, superactive, mesic Aridic Haplustolls) in the semiarid central Great Plains. Winter triticale ( $\times$ Triticosecale Wittm.), winter lentil (Lens culinaris Medik.), spring lentil, spring pea (Pisum sativum L. ssp.), and spring triticale CCs were compared with wheat-fallow and continuous wheat under no-till management. We also studied the effect of triticale haying on soil properties. Results indicate that spring triticale and spring lentil increased soil aggregate size distribution, while spring lentil reduced the wind erodible fraction by $\mathbf{1 . 6}$ times, indicating that CCs reduced the soil's susceptibility to wind erosion. Cover crops also increased wet aggregate stability and reduced runoff loss of sediment, total $\mathrm{P}$, and $\mathrm{NO}_{3}-\mathrm{N}$. After $5 \mathrm{yr}$, winter and spring triticale increased SOC pool by $2.8 \mathrm{Mg} \mathrm{ha}^{-1}$ and spring lentil increased SOC pool by $2.4 \mathrm{Mg} \mathrm{ha}^{-1}$ in the 0 - to $7.5-\mathrm{cm}$ depth compared with fallow. Triticale haying compared with no haying for $5 \mathrm{yr}$ did not affect soil properties. Nine months after termination, CCs had, however, no effects on soil properties, suggesting that CC benefits are short lived in this climate. Overall, CCs, grown in each fallow phase in no-till, can reduce soil erosion and improve soil aggregation in this semiarid climate.

Abbreviations: CC, cover crops; SOC, soil organic carbon.

W inter wheat is the dominant crop grown within the semiarid central Great Plains of the United States. In this region, approximately $4,650,000$ hectares of wheat are grown annually in a dryland wheatfallow or wheat-summer crop-fallow rotation (NASS, 2012). Approximately, half of this wheat is grown in a wheat-fallow rotation (J. Holman, personal communication, 2012). The fallow period, which lasts approximately $16 \mathrm{mo}$, is intended to store soil water for the subsequent wheat phase. Precipitation storage efficiency (fraction of precipitation that is stored in the soil) during fallow, however, ranges only from 10 to 40\% (Nielsen and Vigil, 2010; Hansen et al., 2012). The lower values correspond to conventional till, but even with the use of reduced till and no-till, fallow phase may not store more than $40 \%$ of precipitation (Hansen et al., 2012). In eastern Colorado, Nielsen and Vigil (2010) reported that mean precipitation storage efficiency of a 14-mo fallow under wheat-fallow systems was $20 \%$ for conventional till and 35\% for no-till. The use of fallow is also often at the expense of increased SOC losses (Peterson et al., 1998; Sherrod et al., 2003; Blanco-Canqui et al., 2010), increased soil erosion by wind and water (Merrill et

Soil Sci. Soc. Am. J. 77:1026-1034

doi:10.2136/sssaj2013.01.0006

Received 2 Mar. 2013.

*Corresponding author (hblancocanqui2@unl.edu).

(C) Soil Science Society of America, 5585 Guilford Rd., Madison WI 53711 USA

All rights reserved. No part of this periodical may be reproduced or transmitted in any form or by

any means, electronic or mechanical, including photocopying, recording, or any information storage and retrieval system, without permission in writing from the publisher. Permission for printing and for reprinting the material contained herein has been obtained by the publisher. 
al., 1999; Sharratt and Feng, 2009), and degraded soil properties (Shaver et al., 2003) due to the lack of residue input during fallow and reduced crop frequency.

Growing cover or forage crop in place of fallow in wheatfallow systems may be a strategy to sequester SOC, conserve soil, improve soil properties, and sustain agricultural productivity in semiarid regions. Fallow replacement crops managed under no-till crop rotations may restore some of the SOC lost with intensive tillage. Estimates indicate the original $\mathrm{C}$ pools have declined by about $50 \%$ in the semiarid regions since the introduction of intensive tillage for crop production (Peterson et al., 1998). Studies have shown that intensification of no-till cropping systems due to annual residue input can improve soil properties and store more SOC than no-till crop-fallow systems in the semiarid central Great Plains (Peterson et al., 1998). In western Kansas, Blanco-Canqui et al. (2010) reported that no-till wheat-fallow had lower cumulative water infiltration, effective porosity, and SOC concentration compared with no-till continuous wheat after $33 \mathrm{yr}$ of management. Thus, additional biomass input by CCs may further enhance the performance of no-till crop-fallow systems for conserving soil and increasing SOC storage.

Cover crops can also be a potential practice to reduce wind and water erosion in semiarid regions (Bilbro, 1991; Unger and Vigil, 1998). Wind erosion is a major concern in the Great Plains due to prevalent high winds and low precipitation (Fryrear, 1981). Wind erosion in the Great Plains can range from 5 to $18 \mathrm{Mg} \mathrm{ha}^{-1} \mathrm{yr}^{-1}$ (Hansen et al., 2012). Crop-fallow systems are highly vulnerable to wind erosion due to limited or no residue cover during fallow.

While wind erosion is often a greater concern than water erosion in semiarid regions, water erosion can also be significant, especially in crop-fallow systems. The limited precipitation in the semiarid Great Plains often occurs in the form of intense and localized rainstorms in late spring and summer, which can cause losses of soil and nutrients in runoff. Indeed, increased climate fluctuations with frequent drought and severe and localized rainstorm events in the region may accelerate soil erosion and affect the overall soil and environmental quality. Runoff and soil losses from no-till systems with little or no crop residues may be similar to those from conventionally tilled systems in the central Great Plains under intense rainstorm events (Blanco-Canqui et al., 2009).

Use of CCs in semiarid regions is, however, often questioned due to the limited precipitation input. Cover crops use water and thus may reduce available water for subsequent crops (Unger and Vigil, 1998). The few studies involving CCs from the semiarid central Great Plains reported a reduction in wheat yield in wheat-fallow systems after the fallow phase was replaced with green manures managed under conventional till (Schlegel and Havlin, 1997; Nielsen and Vigil, 2005). The negative effects of CCs on wheat yield can be particularly high in years with low precipitation compared with years with normal precipitation (Nielsen and Vigil, 2005). Despite these drawbacks, interest in using CCs is increasing in the semiarid central Great Plains. Some producers in the central Great Plains are planting CCs (single and mixtures) to explore possible benefits on nutrient cycling and soil conservation. This interest warrants more comprehensive research not only in terms of short-term benefits to crop yields but also in regards to long-term benefits to soil conservation, soil and environmental quality, and sustainable agriculture.

Some producers want to remove the biomass from CCs as forage. Haying of CCs may generate some economic returns to offset any decreases in main crop yields due to cover cropping, however, it reduces the amount of residue left on the soil surface. Haying of CCs may partially reduce the purpose of cover cropping to conserve soil and water resources and enhance soil productivity. More information on the CC effects on soil properties is needed for different scenarios of CC management in the central Great Plains. Some previous studies in this region evaluated effects of CCs as "green manures" on water use, $\mathrm{N}$ contribution, and grain yields managed under conventional till and not on soil erosion, soil physical properties, and SOC storage under no-till systems (Schlegel and Havlin, 1997; Tanaka et al., 1997; Nielsen and Vigil, 2005; Allen et al., 2011). The potential of CCs for improving soil properties and storing SOC may vary with cover crop species, tillage management, soil type, and climate (Olson et al., 2010; Fronning et al., 2008; BlancoCanqui et al., 2011).

The objective of this study was to assess the 5 -yr impacts of CC management on soil C pools, wind and water erosion, and soil structural and hydraulic properties for a number of CCs managed under no-till in the semiarid central Great Plains. Our hypothesis was that replacing fallow with CCs in wheatfallow system could increase SOC pool, reduce soil erosion, and improve soil properties in this climate.

\section{MATERIAL AND METHODS Study Description}

Cover crops were selected from a larger experiment of fallow replacement crops (cover crops, annual forages, or shortseason grain crops) located at the Kansas State UniversitySouthwest Research and Extension Center in Garden City, KS. The soil is a Ulysses silt loam with 1 to $3 \%$ slope. The fallow replacement crops consisting of winter and spring crop species were grown during the fallow period of a no-till wheat-fallow cropping system every year beginning 2007 . The study design was a split-split-plot randomized complete block design with four replications; crop phase was the main plot, crop species was the split-plot, and termination method (forage, grain, or cover) was the split-split-plot. Each split-split-plot was $4.6 \mathrm{~m}$ wide and $36.6 \mathrm{~m}$ long.

Crops were either grown as cover, harvested for forage (annual forage crop), or harvested for grain and were all managed under no-till. Winter species included yellow sweet clover [Melilotus officinalis (L.) Lam.], hairy vetch (Vicia villosa Roth ssp.), lentil, Austrian winter forage pea, Austrian winter grain pea, and triticale. Spring species included lentil, forage pea, grain pea, and triticale. These crops were grown as the sole 
crop or in legume-triticale mixtures. Grain crops were grown in sole crop only. Winter lentil was grown in place of yellow sweet clover beginning in 2009 due to poor performance of yellow sweet clover. Crops grown in place of fallow were compared with a wheat-fallow rotation and with continuous wheat. There were 16 treatments.

Winter crops were planted approximately 1 October. Winter cover and forage crops were chemically terminated or harvested approximately 15 May. Spring crops were planted between the end of February and middle of March. Spring cover and forage crops were chemically terminated or harvested approximately 1 June. Winter and spring grain peas were harvested with a small plot combine (Model Delta, Wintersteiger, Innkreis, Austria) at grain maturity from a $2 \mathrm{~m}$ wide by $36.6 \mathrm{~m}$ long area on about 1 July. Biomass yield from each treatment was measured annually from an area $0.9 \mathrm{~m}$ wide by $36.6 \mathrm{~m}$ long using a small plot forage harvester (Carter Manufacturing Co., Brookston, IN). To assess the effects of haying of cover crops, winter and spring triticale split plots were split into hayed and non-hayed. The CCs were cut at approximately $7.5-\mathrm{cm}$ stubble height. The hay was swathed and baled using field-scale equipment.

Cover crops that had the largest differences in phenotype were selected for this study. Success in the establishment of CCs in this climate was used as another criterion for the selection (Holman et al., 2012). For the study of susceptibility to wind erosion, SOC storage, and other soil properties, seven treatments including winter triticale, winter lentil, spring triticale, spring lentil, spring pea, and two controls (fallow and continuous winter wheat) were selected. For the study of water erosion, five cover crop treatments including winter triticale, winter lentil, spring triticale, spring pea, and control (fallow) were selected. Data on forage yield and quality, wheat yield, and effects of cover crops on soil water dynamics will be reported in a companion study.

\section{Measurement of Water Erosion}

Water erosion was measured under simulated rainfall in early August 2011 when all the crops are terminated. The rainfall simulation study was conducted 2 mo after the termination of spring CCs and about 2 mo before planting of winter wheat. Small 1 - by 2 -m runoff subplots were established at the lower end of the larger cover crop plots to minimize plot disturbance. The subplots were located in non-trafficked rows for all plots. A solenoid-operated and single nozzle rainfall simulator was used to apply rain to each plot for $1 \mathrm{~h}$ at $63.5 \mathrm{~mm} \mathrm{~h}^{-1}$, representing a 5 -yr rainfall return period for the study site (Miller, 1987). The rainfall intensity was achieved through an electrical solenoid valve connected to the simulator.

Two rainfall simulation events, dry and wet run, were performed in each plot. The dry run was done $24 \mathrm{~h}$ before the wet run. Runoff and soil loss were measured during the wet run when treatment plots were under similar initial soil moisture conditions. Each 1- by 2-m runoff plot was bordered with metal sheets except the bottom end where a V-shaped runoff collector was placed to direct runoff to a graduated bucket placed in a soil pit.
Total runoff volume was measured and runoff samples were immediately collected for the determination of nutrients (total $\mathrm{N}$, total $\mathrm{P}, \mathrm{NH}_{4}-\mathrm{N}, \mathrm{NO}_{3}-\mathrm{N}$, and $\mathrm{PO}_{4}-\mathrm{P}$ ) in runoff, sediment concentration, and sediment-associated nutrients from each plot. The collected runoff was manually agitated to resuspend the sediment and obtain representative runoff samples. Runoff water subsamples of $50 \mathrm{~mL}$ were collected and stored in an insulated cooler for the analyses of total $\mathrm{N}$ and total P. The runoff samples for the analyses of total $\mathrm{N}$ and total $\mathrm{P}$ were not filtered. Another runoff subsample was filtered through Whatman syringe filter with a $0.45 \mu \mathrm{m}$ pore size within $10 \mathrm{~min}$ after the end of each rainfall simulation for the analyses of $\mathrm{NO}_{3}-\mathrm{N}, \mathrm{NH}_{4}-\mathrm{N}$, and $\mathrm{PO}_{4}-\mathrm{P}$. These samples for dissolved nutrient analysis were filtered, stored in an insulated cooler, and transported to the laboratory for the determination of $\mathrm{NO}_{3}-\mathrm{N}$, $\mathrm{NH}_{4}-\mathrm{N}$, and $\mathrm{PO}_{4}-\mathrm{P}$ concentrations. Analyses of total $\mathrm{N}$, total $\mathrm{P}$, and dissolved nutrients in runoff samples were done within $48 \mathrm{~h}$ by a Lachat flow injection analyzer (Lachat Quickchem methods 10-107-04-1-A, 10-107-06-2-A, and 10-115-01-1-A).

One liter of runoff sample was collected for the determination of sediment concentration by the evaporation method. This method consisted of weighing the runoff sample before and after oven-drying the sample at $105^{\circ} \mathrm{C}$ (Brakensiek et al., 1979). Another liter of runoff sample was collected for the determination of sediment-associated SOC and total N. This sample was oven-dried at $50^{\circ} \mathrm{C}$ and dry sediment was collected and passed through $0.25-\mathrm{mm}$ sieve for the analysis of SOC and total $\mathrm{N}$ by the dry combustion method (Nelson and Sommers, 1996). The total volume of runoff from each plot was divided by the plot area to determine runoff depth.

\section{Measurement of Wind Erosion Potential}

Soil properties including dry aggregate size distribution, wind erodible fraction, and geometric mean diameter of dry aggregates were used as parameters to evaluate the soil's susceptibility to wind erosion among cover crop treatments. Approximately $2 \mathrm{~kg}$ of soil sample from the 0 - to $5-\mathrm{cm}$ depth was collected with a flat shovel from each plot in summer 2011 at the time of runoff simulation. The soil samples were ovendried at $56^{\circ} \mathrm{C}$ for $48 \mathrm{~h}$ for the determination of dry aggregate size distribution by the rotary sieve (Chepil, 1962; Lyles et al., 1970). Soil aggregates from the rotary sieves were classified into different aggregate-size fractions as follows: $<0.42,0.42-$ to 0.84-, 0.84- to 2-, 2- to 6.35-, 6.35- to 14.05-, 14.05- to 44.45-, and $>44.45-\mathrm{mm}$ in diameter. Wind-erodible fraction was computed as the fraction of soil aggregates with diameter $<0.84$ $\mathrm{mm}$ (Chepil, 1952). Geometric mean diameter of dry aggregates was computed using the mesh size of each sieve and the amount of aggregates within each fraction (Nimmo and Perkins, 2002).

\section{Measurement of Soil Physical Properties and Organic Carbon}

At the time of runoff simulation (early August 2011), two intact soil cores $(7.6 \mathrm{~cm}$ diam. by $7.6 \mathrm{~cm}$ in height $)$ were 
collected from each treatment plot for the 0 - to $7.6-\mathrm{cm}$ soil depth for the determination of soil physical properties. The soil cores were used for the determination of bulk density by the core method (Grossman and Reinsch, 2002) and soil water retention at -33 and $-1500 \mathrm{kPa}$ matric potentials by pressure extractors (Dane and Hopmans, 2002). Additionally, two soil columns were collected using the Giddings hydraulic probe for the 0 - to $30-\mathrm{cm}$ soil depth from each plot. The columns were sliced at the following depth increments: 0- to 7.5-, 7.5- to 15-, 15- to 22.5-, and 22.5- to 30-cm soil depths for the determination of waterstable aggregates and SOC concentration. These soil samples were manually broken down and air-dried for $72 \mathrm{~h}$. A portion of the air-dry sample was crushed and passed through sieves with 4.75- and 8-mm mesh openings to obtain 4.75- to 8-mm airdry aggregates for the determination of water-stable aggregates by the wet sieving method (Nimmo and Perkins, 2002). Sand correction for each aggregate-size fraction followed Kemper and Rosenau (1986). Data on water-stable aggregates were used to compute geometric mean diameter of water-stable aggregates. Another portion of the air-dry soil sample was crushed using a mortar and pestle and passed through a sieve with $0.25-\mathrm{mm}$ mesh openings for the determination of SOC concentration by the dry combustion method (Nelson and Sommers, 1996). The SOC was determined in soil samples treated with $10 \% \mathrm{v} / \mathrm{v}$ of $\mathrm{HCl}$ for the elimination of carbonates. The SOC pool was calculated on an equivalent mass basis approach rather than on a fixed depth basis. The equivalent mass basis approach accounts for any differences in soil bulk density among the treatments (Ellert et al., 2001, 2002). Baseline data on SOC concentration were collected for each plot (Table 1).

\section{Measurement of Soil Properties after Cover Crop Termination}

Soil properties including dry aggregate size distribution, water-stable aggregates, bulk density, and SOC concentration were measured again in early March 2012 (9 mo after cover crop termination) to assess the longevity of cover crop effects following termination. In addition, water infiltration was measured using double-ring infiltrometers to estimate cover crop impacts on precipitation capture (Reynolds et al., 2002). The inner ring of the double-ring infiltrometers had a diameter of $15 \mathrm{~cm}$, while the outer ring had a diameter of $27 \mathrm{~cm}$. The rings were inserted

Table 1. Mean soil organic carbon (SOC) data for the 0- to $10-\mathrm{cm}$ depth collected at the experiment onset in 2007 for the cover crop experiment at Garden City, KS. Samples were collected from each plot.

\begin{tabular}{lrc}
\multicolumn{1}{c}{ Treatment } & SOC & \multicolumn{2}{c}{ Standard deviation } \\
\hline & & $\mathrm{g} \mathrm{kg}^{-1}-$ \\
Fallow & 9.0 & 1.0 \\
Winter lentil & 9.0 & 0.7 \\
Spring pea & 10.1 & 1.3 \\
Spring lentil & 8.9 & 1.6 \\
Winter triticale & 8.9 & 1.1 \\
Spring triticale & 9.3 & 1.3 \\
Continuous winter wheat & 8.6 & 1.1 \\
\hline
\end{tabular}

into the soil to $15-\mathrm{cm}$ depth, and infiltration was measured for $3 \mathrm{~h}$. Infiltration measurements were performed at two positions within non-trafficked rows in each plot. All treatment plots were under winter wheat crop at this time. As in the previous year, soil samples for the determination of dry aggregate size distribution and calculation of wind erodible fraction and geometric mean diameter of dry aggregates were collected from the $0-$ to $5-\mathrm{cm}$ depth. Bulk samples and soil cores were collected from the 0 - to $7.5-\mathrm{cm}$ soil depth for the determination of bulk density, water-stable aggregates, and SOC concentration. Measurement protocols for soil properties were the same as for the study conducted in summer 2011.

\section{Statistical Analysis of Data}

Statistical differences among cover crop treatments were analyzed using PROC MIXED in SAS (SAS Institute, 2012). Cover crops were considered as the main plots and replications as random for the analysis of cover crop effects. However, for the study of effects of winter and spring triticale haying on soil properties, the two cover crops were considered as main plots, haying as subplot, and replications as random. Separation of treatment means was performed using least significant differences at the 0.05 probability level unless otherwise specifically mentioned. Correlations between soil physical properties and CC-induced changes in SOC concentration were performed without the data on continuous wheat and winter and spring triticale haying to assess the sole effects of CCs on improving soil properties in wheat-fallow systems.

\section{RESULTS}

\section{Soil Organic Carbon Concentration and Pool}

Cover crops increased SOC concentration and pool in the 0 - to $7.5-\mathrm{cm}$ soil depth but not at deeper depths (data not shown) relative to fallow (Table 2). Because trends in SOC concentration and pools were similar, only results on SOC pool are discussed. Effects varied with CC species. Winter and spring triticale, and spring lentil increased SOC pool by an average of 1.2 times compared with fallow, but winter lentil and spring pea had no effects (Table 2). On average, triticale CCs increased the SOC pool by $2.8 \mathrm{Mg} \mathrm{ha}^{-1}$ and spring lentil by $2.4 \mathrm{Mg} \mathrm{ha}^{-1}$.

The greater SOC pool in triticale is attributed to the greater residue input from triticale compared with other CCs. Residue yield, averaged across 2008, 2009, 2010, and 2011, was $4.12 \mathrm{Mg} \mathrm{ha}^{-1}$ for winter triticale, $2.09 \mathrm{Mg} \mathrm{ha}^{-1}$ for spring triticale, $1.60 \mathrm{Mg} \mathrm{ha}^{-1}$ for spring pea, $0.43 \mathrm{Mg} \mathrm{ha}^{-1}$ for spring lentil, and $0.30 \mathrm{Mg} \mathrm{ha}^{-1}$ for winter lentil. The SOC pool between spring lentil and spring pea did not differ in spite of lower residue yield in spring lentil than in spring pea. Cover crops did not increase SOC pool relative to continuous wheat. In fact, CCs, with the exception of spring triticale, stored less SOC than continuous wheat (Table 2). Compared with fallow, continuous wheat had 1.4 times greater SOC pool (Table 2).

Differences in rainfall input among years appeared to dictate $\mathrm{CC}$ biomass production and thus differences in SOC pool. For 
Table 2. Cover crop effects on bulk density and soil organic carbon (SOC) pool on an equivalent mass basis for the $0-$ to $7.5-\mathrm{cm}$ soil depth for summer 2011 and spring 2012.

\begin{tabular}{|c|c|c|c|c|c|c|c|c|}
\hline \multirow{2}{*}{ Treatment } & \multirow{2}{*}{ Subplot } & \multicolumn{4}{|c|}{ Summer 2011} & \multicolumn{3}{|c|}{ Spring 2012} \\
\hline & & Bulk density & SOC & SOC & Difference & Bulk density & SOC & SOC \\
\hline & & $\mathrm{Mg} \mathrm{m}^{-3}$ & $\mathrm{~g} \mathrm{~kg}^{-1}$ & \multicolumn{2}{|c|}{ — Mg ha ${ }^{-1}$} & $\mathrm{Mg} \mathrm{m}^{-3}$ & $\mathrm{~g} \mathrm{~kg}^{-1}$ & $\mathrm{Mg} \mathrm{ha}^{-1}$ \\
\hline Fallow & & 1.57 & $8.7 \mathrm{dt}$ & $10.9 d$ & & 1.49 & 8.8 & 9.9 \\
\hline Winter lentil & & 1.45 & $9.2 \mathrm{~cd}$ & $11.3 \mathrm{~cd}$ & 0.4 & 1.40 & 9.3 & 10.4 \\
\hline Spring pea & & 1.55 & $10.1 \mathrm{bcd}$ & $12.5 \mathrm{bcd}$ & 1.6 & 1.42 & 10.2 & 11.5 \\
\hline Spring lentil & & 1.49 & $10.8 \mathrm{bc}$ & $13.3 \mathrm{bc}$ & 2.4 & 1.48 & 10.8 & 12.0 \\
\hline \multirow{2}{*}{ Winter triticale } & Cover & 1.39 & $11.4 \mathrm{bcA} \neq$ & $13.4 \mathrm{bcA}$ & 2.5 & 1.49 & 9.4 & 10.6 \\
\hline & Hayed & 1.46 & $9.4 \mathrm{~A}$ & $11.7 \mathrm{~A}$ & 0.8 & 1.50 & 9.9 & 11.2 \\
\hline \multirow{2}{*}{ Spring triticale } & Cover & 1.44 & 11.6abA & 14.0abA & 3.1 & 1.47 & 10.4 & 11.5 \\
\hline & Hayed & 1.45 & $12.1 \mathrm{~A}$ & $14.4 \mathrm{~A}$ & 3.5 & 1.40 & 9.9 & 11.5 \\
\hline Continuous winter wheat & & 1.45 & $13.0 \mathrm{a}$ & $15.6 \mathrm{a}$ & 4.7 & 1.40 & 10.6 & 12.1 \\
\hline
\end{tabular}

example, averaged across all years, winter triticale produced more biomass than other CCs; but in 2011, due to the drought, winter triticale $\left(0.95 \mathrm{Mg} \mathrm{ha}^{-1}\right)$ produced less biomass than spring triticale $\left(1.58 \mathrm{Mg} \mathrm{ha}^{-1}\right)$. The only rain that occurred was in the spring, which favored spring triticale over winter triticale. This may, in part, explain the significant gains in SOC with spring triticale in 2011. As discussed later, CCs, in this study, had shortterm beneficial effect on SOC. If we had measured SOC in the previous year (2010), SOC pool in winter triticale may have been greater than in spring triticale. The reason for this hypothesis is winter triticale produced more biomass than spring triticale in the previous years. Mean annual precipitation for 2011 was $63 \%$ $(308 \mathrm{~mm}$ ) of the 30 -yr average $(489 \mathrm{~mm})$ for the site (Table 3).

\section{Wind Erosion and Water Erosion}

Cover crops affected the indicators of soil's susceptibility to wind erosion such as erodible fraction and geometric mean diameter of dry aggregates, but the differences were significant only at the 0.10 probability level. Similar to SOC pool, effects varied with CC species. Spring triticale and spring lentil increased geometric mean diameter of dry aggregates by 1.6 times compared with fallow (Fig. 1a). Spring lentil reduced wind erodible fraction by 1.8 times (Fig. 1b). Other CCs, particularly winter CCs, had no effects on soil wind erodibility properties.

Continuous wheat had the highest geometric mean diameter of dry aggregates (Fig. 1a) and the lowest amount of wind erodible fraction of all treatments (Fig. 1b). It increased geometric mean diameter by 1.8 times and reduced soil erodible fraction by 2.2 times compared with fallow. Differences in these soil properties between continuous wheat and CCs were not significant, suggesting that CCs were not superior to continuous wheat to control wind erosion.

Cover crops also affected water erosion at the 0.10 probability level (Fig. 2a, 2b, 2c). Differences were found in time to runoff $(P=0.07$; Fig. 2a), runoff depth $(P=0.10$; Fig. $2 \mathrm{~b})$, and sediment loss $(P=0.10$; Fig. $2 \mathrm{c})$. Loss of sedimentassociated total $\mathrm{P}(P=0.10)$, and $\mathrm{NO}_{3}-\mathrm{N}(P=0.10)$ among CCs was also significant (Table 4). Losses of total $\mathrm{N}, \mathrm{NH}_{4}-\mathrm{N}$, and $\mathrm{PO}_{4}-\mathrm{P}$ in runoff and sediment-associated $\mathrm{C}$ and total $\mathrm{N}$ were, however, unaffected (Table 4).

Runoff from winter triticale plots started 24 min after runoff started from fallow plots, but winter lentil, spring triticale, and spring pea had no effects compared with fallow (Fig. 2a). Compared with spring triticale and spring pea, winter triticale

Table 3. Precipitation data from 2007 to 2011 for the cover crop experiment at Garden City, KS.

\begin{tabular}{lllllll}
\multirow{2}{*}{ Month } & \multicolumn{6}{c}{ Precipitation input } \\
\cline { 2 - 7 } & $\mathbf{2 0 0 7}$ & $\mathbf{2 0 0 8}$ & $\mathbf{2 0 0 9}$ & $\mathbf{2 0 1 0}$ & $\mathbf{2 0 1 1}$ & $\mathbf{3 0 - y r}$ avg. \\
\cline { 2 - 7 } January & 15 & 8 & 2 & 18 & 5 & 12 \\
February & 15 & 15 & 2 & 10 & 11 & 14 \\
March & 46 & 8 & 29 & 46 & 17 & 33 \\
April & 74 & 42 & 111 & 57 & 45 & 44 \\
May & 30 & 49 & 47 & 99 & 29 & 76 \\
June & 64 & 79 & 94 & 37 & 43 & 79 \\
July & 43 & 30 & 80 & 33 & 14 & 71 \\
August & 66 & 64 & 56 & 69 & 62 & 64 \\
September & 53 & 18 & 41 & 8 & 9 & 36 \\
October & 5 & 119 & 76 & 19 & 11 & 31 \\
November & 3 & 9 & 10 & 2 & 11 & 14 \\
December & 34 & 1 & 5 & 2 & 52 & 15 \\
Annual & 448 & 440 & 552 & 400 & 308 & 489 \\
\hline
\end{tabular}


delayed runoff initiation by about $20 \mathrm{~min}$. Winter triticale, spring pea, and spring triticale reduced runoff depth by 3.5 times relative to fallow, but winter lentil had no effect. Sediment loss from winter triticale and spring pea was 3.7 times lower than from fallow. Runoff depth and sediment loss between winter triticale and spring triticale did not differ. Loss of total $\mathrm{P}$ and $\mathrm{NO}_{3}-\mathrm{N}$ in runoff was 3.4 to 4.2 times less in winter triticale and spring pea than in fallow.

\section{Soil Physical Properties}

Particle-size distribution, as expected, was not affected by CCs. Mean values averaged across all CC treatments were $199 \mathrm{~g} \mathrm{~kg}^{-1}$ for sand, $471 \mathrm{~g} \mathrm{~kg}^{-1}$ for silt, and $330 \mathrm{~g} \mathrm{~kg}^{-1}$ for clay. Similarly, CCs had no effects on bulk density (Table 2) and soil water retention (data not shown), but had large and significant effects on geometric mean diameter of water-stable aggregates (Fig. 1c). Effects of CCs on water-stable aggregates were significant only for the $0-$ to $7.5-\mathrm{cm}$ soil depth. All CCs
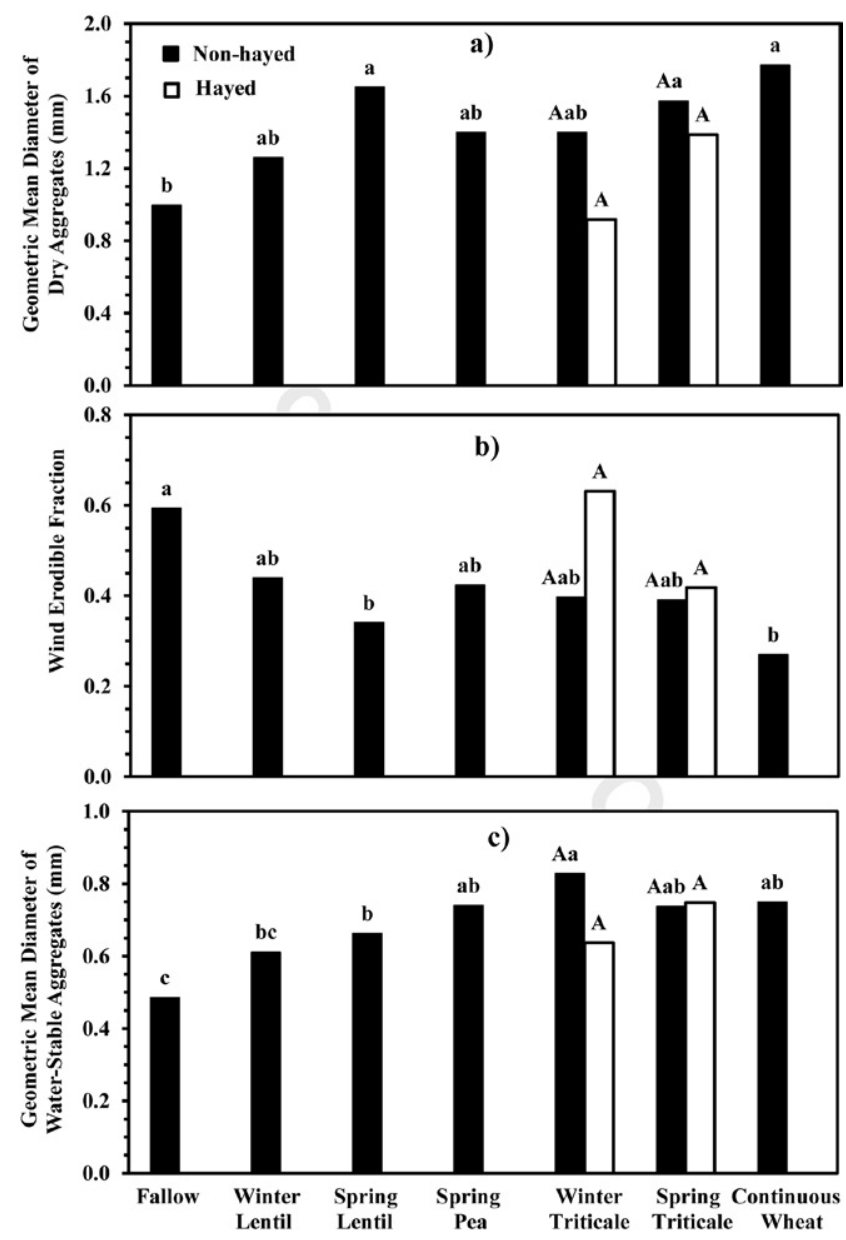

Fig. 1. Impacts of winter and spring cover crops on (a) dry soil aggregate size distribution expressed as geometric mean diameter of aggregates, (b) wind erodible fraction $(<0.84-\mathrm{mm}$ aggregates), and (c) geometric mean diameter of water-stable aggregates in summer 2011 (2 mo after crop termination). Dry aggregate size distribution was measured for the 0 - to $5-\mathrm{cm}$ soil depth, while wet aggregate stability was measured for the 0 - to $7.5-\mathrm{cm}$ depth. Means followed with the same lowercase letter are not significantly different. Means with the same uppercase letter for hayed (white bars) and non-hayed (black bars) winter and spring triticale are not significantly different. increased wet aggregate stability relative to fallow except winter lentil. Winter triticale increased geometric mean diameter of water-stable aggregates by 1.7 times while spring CCs (triticale, lentil, and peas) increased geometric mean diameter by 1.5 times. Differences in geometric mean diameter between CCs and continuous wheat were not significant, but continuous wheat had greater geometric mean diameter of water-stable aggregates than fallow.

\section{Triticale Haying and Residual Effects of Cover Crops on Soil Properties}

Haying of winter and spring triticale CCs had no significant effect on any soil and erosion parameter (Fig. 1a, 1b, 1c; Table 2). These results suggest that haying may not have negative effects on soil properties in the short term in this climate. While differences were not statistically significant, haying of winter triticale tended to reduce SOC pool, increase wind erodible fraction, and reduce geometric mean diameter of dry and water-stable aggregates. Based on this trend, we hypothesize that haying effects may be significant in the longer term.

Data collected 9 mo after CC termination (spring 2012) in this experiment allowed the evaluation of the residual effects of CCs on soil properties. As presented earlier, data collected in summer 2011 (2 mo after CC termination) indicated that CCs, in general, increased SOC pool, reduced potential of water and wind erosion, and improved soil aggregation (Fig. 1a, 1b, $1 \mathrm{c}$ and 2a, 2b, 2c; Table 2). However, data collected 9 mo after CC termination (spring 2012) indicated that CC had no effect on any soil property, indicating that $\mathrm{CC}$ effects are short-lived after termination. Because data were not significant, results from spring 2012 are not presented.

\section{DISCUSSION}

Results supported our hypothesis, suggesting that replacing fallow with CCs can reduce erosion, improve soil properties, and restore some of the SOC lost from wheat-fallow systems in semiarid regions. Because of their higher biomass production than other CCs, particularly legumes (Holman et al., 2012), winter and spring triticale appeared to be the best CC species to enhance the potential of no-till wheat-fallow systems for improving soil properties. Legume CCs such as peas may also be grown for forage or grain between main crops but provide limited biomass cover to protect soil from erosion (Miller et al., 2006). The slightly greater effectiveness of continuous wheat than CCs for increasing SOC may be due to the abundant and uniform surface residue cover under continuous wheat.

The increase in SOC with both CCs and continuous wheat relative to fallow suggests that intensification of cropping systems or elimination of fallow periods under no-till systems may restore SOC and improve soil structural properties in wheat-fallow systems. In the central Great Plains, increased adoption of no-till in recent decades has allowed intensification of cropping systems and reduction in fallow periods due to enhanced precipitation capture and water use efficiency (Peterson and Westfall, 2004; 
Nielsen and Vigil, 2010). Increased residue input from intensified cropping systems interacts with reduced soil disturbance in notill to improve soil properties and productivity (Shaver et al., 2003; Blanco-Canqui et al., 2010).

Our study indicates that cover cropping can reduce soil's susceptibility to erosion in this semiarid soil. Wind erosion is particularly a major concern in the study region in late winter and early spring (February and March) when winds are strong, precipitation is low, and soil surface cover is limited. During this period, winter wheat is short and does not provide a dense cover to protect soil from erosion. Intensified cropping systems by replacing fallow with $\mathrm{CCs}$ and other crops can provide additional biomass cover to protect soil from erosion and improve ecosystem function of cropping systems. Our results agree with Bilbro (1991) who found that CCs consisting of winter rye (Secale cereale L.) planted with forage sorghum [Sorghum bicolor (L.) Moench] in alternate $12.5-\mathrm{cm}$ rows provided adequate soil cover and reduced wind erosion potential on a fine sandy loam near Amarillo, TX.

Our results also suggest that the positive effects of CCs on reducing soil's susceptibility to water and wind erosion may depend on the amount of residue input during fallow periods. The reduced biomass yield of winter CCs in 2011 in response to limited rainfall input in winter 2011 may explain their limited effectiveness relative to spring CCs. While differences in biomass yield probably determined changes in soil wind erodibility properties, the greater beneficial effects of spring CCs compared with winter CCs may also be partly due to differences in winter and spring CC termination dates. This study was conducted about 3 mo after winter $\mathrm{CC}$ termination and about 2 mo after spring CC termination. The residual or beneficial effects of CCs may decrease rapidly with time after termination in this climate as discussed later.

The lower losses of runoff and sediment under CCs than under fallow support similar findings from regions (i.e., Missouri, Iowa) with higher precipitation input (Zhu et al., 1989; Kaspar et al., 2001). In the study region, rainstorms often occur in late spring and summer. The reduced runoff loss under CCs may contribute to water conservation. Runoff depth from fallow plots was $45 \mathrm{~mm} \mathrm{~h}^{-1}$ under $63.5 \mathrm{~mm} \mathrm{~h}^{-1}$ of simulated rainfall (Fig. 2b). This means that $71 \%$ of simulated rainfall was lost as runoff from fallow. Based on similar analysis (Fig. 2b), only $13 \%$ of rain was lost as runoff from winter triticale, spring pea, and spring triticale plots, suggesting that CCs can reduce loss of runoff water in intense rainfall events, offsetting, at some degree, the amount of water used by CCs growth. Studies in the region found that CCs can reduce soil water for subsequent crops (Schlegel and Havlin, 1997; Nielsen and Vigil, 2005).
Table 4. Mean losses of nutrients in runoff and sediment under simulated rainfall in summer 2011 (2 mo after cover crop termination) for five cover crop treatments after 5 yr of management in no-till winter wheat rotated with fallow or cover crop on an Aridic Haplustoll. Water erosion was studied only for five cover crop treatments.

\begin{tabular}{|c|c|c|c|c|c|c|c|}
\hline \multirow{2}{*}{ Cover crop } & \multicolumn{5}{|c|}{ Nutrients dissolved in runoff } & \multicolumn{2}{|c|}{ Sediment-associated nutrients } \\
\hline & Total $\mathbf{N}$ & Total P & $\mathrm{NH}_{4}-\mathrm{N}$ & $\mathrm{NO}_{3}-\mathrm{N}$ & $\mathrm{PO}_{4}-\mathrm{P}$ & Organic C & Total $\mathbf{N}$ \\
\hline & \multicolumn{5}{|c|}{$\mathrm{kg} \mathrm{ha}^{-1}$} & \multicolumn{2}{|c|}{$-\mathrm{Mg} \mathrm{ha}^{-1}$} \\
\hline Fallow & 7.60 & 0.44at & 0.20 & $5.96 a$ & 0.30 & 0.012 & 0.006 \\
\hline Winter lentil & 4.21 & $0.27 \mathrm{ab}$ & 0.09 & $3.36 \mathrm{ab}$ & 0.17 & 0.010 & 0.004 \\
\hline Spring triticale & 3.41 & $0.23 \mathrm{ab}$ & 0.19 & $2.55 a b$ & 0.22 & 0.006 & 0.003 \\
\hline Spring pea & 2.08 & $0.10 \mathrm{~b}$ & 0.04 & $1.66 \mathrm{~b}$ & 0.06 & 0.005 & 0.002 \\
\hline Winter triticale & 1.91 & $0.13 b$ & 0.12 & $1.41 b$ & 0.12 & 0.003 & 0.002 \\
\hline$P>F$ & 0.13 & 0.10 & 0.54 & 0.10 & 0.13 & 0.31 & 0.15 \\
\hline
\end{tabular}

† Means followed by different letter within columns are significantly different at 0.10 probability level. 
CC-induced increase in SOC concentration, suggesting that increase in SOC was partly responsible for the improvement in soil structural stability (Tisdall and Oades, 1982). The SOC can promote macroaggregation and increase the aggregate stability through biological and physicochemical bonding mechanisms (Tisdall and Oades, 1982; Colazo and Buschiazzo, 2010). Our results cannot be directly compared with other studies as there is limited information on CC effects on soil properties in the central Great Plains under no-till conditions. Most previous studies in this region focused on water use and grain yields in CCs used as green manure under conventional till (Schlegel and Havlin, 1997; Nielsen and Vigil, 2005; Felter et al., 2006; Lyon et al., 2007).

The lack of triticale CC haying effects on soil properties after $5 \mathrm{yr}$ deserves discussion. Although we did not quantify the amount of root biomass in this study, the lack of haying effects suggest that belowground biomass (i.e., roots) under CCs possibly maintained SOC and aggregate properties (Rutz et al., 2012). Furthermore, the aboveground biomass may have also minimized the haying effects as not all aboveground biomass was removed through haying. Also, although plant regrowth was controlled with the use of herbicides in this study, some plant regrowth occurred after hay harvest in some years when moisture was sufficient. Long-term monitoring of haying effects is needed to conclusively ascertain the implications of CC haying on soil properties. In the short term, haying of CCs may not reduce the CC benefits, and it may be economically profitable since limited economic value is gained from not harvesting a CC.

The lack of significant differences in soil properties 9 mo after CC termination (spring2012) strongly suggests that the beneficial effects of CCs on soil erosion control and improvement in soil properties diminished rapidly with time after CC termination. Soil benefits due to CCs are short-lived if CCs are terminated. These results have implications for the management of CCs in semiarid regions. They suggest that CC growth or termination should be near to times when water and wind erosion events are most likely to occur as benefits apparently are lost rapidly with time after termination.

Results suggest that CC residues left on the soil surface decomposed rapidly in this semiarid climate, reducing the protective cover and any positive residual effects needed to maintain the CC-induced improvements in SOC concentration and soil physical properties. Overwinter processes including abrupt fluctuations in wetting and drying and freezing and thawing possibly also contributed to the reduction in the beneficial effects of CCs on soil aggregation. Results therefore suggest that CCs should be grown in each fallow phase in wheat-fallow systems to provide benefits through continuous surface cover.

\section{CONCLUSIONS}

Replacing fallow with CCs in no-till wheat-fallow after $5 \mathrm{yr}$ in a semiarid soil in the central Great Plains, in general, reduced the potential for wind and water erosion, improved soil aggregation, and increased SOC pool, indicating that growing CCs in place of fallow had significant benefits on soil properties. Continuous wheat was as effective as or better than most CCs, which suggests that intensification of wheat-fallow with continuous cropping or CCs can improve soil properties. Results also showed that the beneficial effects of CC residues can rapidly decrease after CC termination in this semiarid climate. Nine months after CC termination, the effects of CCs on soil properties were not significant compared with fallow, suggesting that CCs should be grown each fallow phase to maintain benefits. Triticale CC haying did not affect soil properties in the short term, but further research is needed to determine long-term $(>5 \mathrm{yr})$ haying effects. Winter and spring triticale due to their higher residue input than other CCs appear to be the most effective CCs for reducing erosion and improving aggregation in this semiarid soil. Overall, intensification of cropping systems with CCs and continuous cropping under no-till management may be an improved management alternative to wheat-fallow systems in this region. Additional studies in the region are, however, needed to identify the best cover cropping systems (i.e., single and mixed cover crop plantings) and develop site-specific CC management strategies (i.e., termination methods and dates) to conserve soil and water and and enhance crop production in semiarid regions. It is also important to perform an economic analysis of the different CCs to assess both their soil and economic benefits.

\section{ACKNOWLEDGEMENTS}

This research work was funded by the Ogallala Aquifer Program-USDA Agricultural Research Service. Comments provided by Dr. Charles Wortmann during the preparation of the manuscript are greatly appreciated.

\section{REFERENCES}

Allen, B.L., J.L. Pikul, J.T. Waddell, and V.L. Cochran. 2011. Long-term lentil green-manure replacement for fallow in the semiarid northern Great Plains. Agron. J. 103:1292-1298. doi:10.2134/agronj2010.0410

Bilbro, J.D. 1991. Cover crops for wind erosion control in semiarid regions. In: W.L. Hargrove, editor, Cover crops for clean water. Proceedings of an International Conference West Tennessee Experiment Station, Jackson, TN. April 9-11 Apr. 1991. Soil and Water Conserv. Soc., Ankeny, IA.

Blanco-Canqui, H., M.M. Mikha, D.R. Presley, and M.M. Claassen. 2011. Addition of cover crops enhances no-till potential for improving soil physical properties. Soil Sci. Soc. Am. J. 75:1471-1482. doi:10.2136/ sssaj2010.0430

Blanco-Canqui, H., R. Stephenson, N.O. Nelson, and D.R. Presley. 2009. Impacts of crop residue removal as biofuel feedstocks on runoff, sediment, and nutrient losses. J. Environ. Qual. 38:2365-2372. doi:10.2134/jeq2009.0021

Blanco-Canqui, H., L.R. Stone, and P.W. Stahlman. 2010. Soil response to longterm cropping systems on an Argiustoll in the central Great Plains. Soil Sci. Soc. Am. J. 74:602-611. doi:10.2136/sssaj2009.0214

Brakensiek, D.L., H.B. Osborn, and W.J. Rawls. 1979. Field manual for research in agricultural hydrology. USDA Handb. 224. U.S. Gov. Print. Office, Washington, DC.

Chepil, W.S. 1962. A compact rotary sieve and the importance of dry sieving in physical soil analysis. Soil Sci. Soc. Am. Proc. 26:4-6. doi:10.2136/ sssaj1962.03615995002600010002x

Chepil, W.S. 1952. Improved rotary sieve for measuring state and stability of dry soil structure. Soil Sci. Soc. Am. Proc. 16:113-117. doi:10.2136/ sssaj1952.03615995001600020001x

Colazo, J.C., and D.E. Buschiazzo. 2010. Soil dry aggregate stability and wind erodible fraction in a semiarid environment of Argentina. Geoderma 159:228-236. doi:10.1016/j.geoderma.2010.07.016

Dane, J.H., and J.H. Hopmans. 2002. Water retention and storage. In: J.H. Dane 
and G.C. Topp, editors, Methods of soil analysis. Part 4. SSSA Book Ser. 5. SSSA, Madison, WI. p. 671-717.

Ellert, B.H., H.H. Janzen, and T. Entz. 2002. Assessment of a method to measure temporal change in soil carbon storage. Soil Sci. Soc. Am. J. 66:1687-1695. doi:10.2136/sssaj2002.1687

Ellert, B.H., H.H. Janzen, and B.G. McConkey. 2001. Measuring and comparing soil carbon storage. In: R. Lal et al., editors, Soil processes and the carbon cycle. CRC Press, Boca Raton, FL. p. 131-146.

Felter, D.G., D.J. Lyon, and D.C. Nielsen. 2006. Evaluating crops for a flexible summer fallow cropping system. Agron. J. 98:1510-1517. doi:10.2134/ agronj2005.0341

Fronning, B.E., K.D. Thelen, and D. Min. 2008. Use of manure, compost and cover crops to supplant crop residue carbon in corn stover removed cropping systems. Agron. J. 100:1703-1710. doi:10.2134/agronj2008.0052

Fryrear, D.W. 1981. Dust storms in the southern Great Plains. Trans. ASAE 24:991-994.

Grossman, R.B., and T.G. Reinsch. 2002. Bulk density and linear extensibility. In: J.H. Dane and G.C. Topp, editors, Methods of soil analysis. Part 4. SSSA Book Ser. 5. SSSA, Madison, WI. p. 201-225.

Hansen, N.C., B.L. Allen, R.L. Baumhardt, and D.J. Lyon. 2012. Research achievements and adoption of no-till, dryland cropping in the semi-arid U.S. Great Plains. Field Crops Res. 132:196-203. doi:10.1016/j.fcr.2012.02.021

Holman, J., T. Dumler, T. Roberts, and S. Maxwell. 2012. Cover crop forage biomass yield. Field Day 2012. Rep. of Progress 1070. K-State Res. and Ext. Kansas State Univ. Agric. Exp. Stn. and Coop. Ext. Serv. Southwest Res.-Ext. Ctr. http://www.southwest.ksu.edu/doc39646.ashx (accessed 15 Nov. 2012). p. 12-17.

Kaspar, T.C., J.K. Radke, and J.M. Laflen. 2001. Small grain cover crops and wheel traffic effects on infiltration, runoff, and erosion. J. Soil Water Conserv. 56:160-164.

Kemper, W.D., and R.C. Rosenau. 1986. Aggregate stability and size distribution. In: A. Klute, editor, Methods of soil analysis. Part 1. Physical and mineralogical methods. 2nd ed. SSSA Book Ser. 5. SSSA, Madison, WI. p. 425-442.

Lyles, L., J.D. Dickerson, and L.A. Disrud. 1970. Modified rotary sieve for improved accuracy. Soil Sci. 109:207-2 10.

Lyon, D.J., D.C. Nielsen, D.G. Felter, and P.A. Burgener. 2007. Choice of summer fallow replacement crops impacts subsequent winter wheat. Agron. J. 99:578-584. doi:10.2134/agronj2006.0287

Merrill, S.D., A.L. Black, D.W. Fryrear, A. Saleh, T.M. Zobeck, A.D. Halvorson, and D.L. Tanaka. 1999. Soil wind erosion hazard of spring wheat-fallow as affected by long-term climate and tillage. Soil Sci. Soc. Am. J. 63:17681777. doi:10.2136/sssaj1999.6361768x

Miller, P.R., R.E. Engel, and J.A. Holmes. 2006. Cropping sequence effect of pea and pea management on spring wheat in the northern Great Plains. Agron. J. 98:1610-1619. doi:10.2134/agronj2005.0302

Miller, W.P. 1987. A solenoid-operated, variable intensity rainfall simulator. Soil Sci. Soc. Am. J. 51:832-834. doi:10.2136/ sssaj1987.03615995005100030048x

NASS. 2012. Quick Stats. Natl. Agric. Statistics Serv. www.nass.usda.gov/ (accessed 21 Oct. 2012).

Nelson, D.W., and L.E. Sommers. 1996. Total carbon, organic carbon, and organic matter: Laboratory methods. In: D.L. Sparks, editor, Methods of soil analysis. Part 3. SSSA Book Ser. 5. SSSA, Madison, WI. p. 961-1010.

Nielsen, D.C., and M.F. Vigil. 2005. Legume green fallow effect on soil water content at wheat planting and wheat yield. Agron. J. 97:684-689. doi:10.2134/agronj2004.0071

Nielsen, D.C., and M.F. Vigil. 2010. Precipitation storage efficiency during fallow in wheat-fallow systems. Agron. J. 102:537-543. doi:10.2134/ agronj2009.0348

Nimmo, J.R., and K.S. Perkins. 2002. Aggregate stability and size distribution. In: J.H. Dane and G.C. Topp, editors, Methods of soil analysis. Part 4. SSSA Book Ser. 5. SSSA, Madison, WI. p. 317-327.

Olson, K.R., S.A. Ebelhar, and J.M. Lang. 2010. Cover crop effects on crop yields and soil organic carbon content. Soil Sci. 175:89-98. doi:10.1097/ SS.0b013e3181cf7959

Peterson, G.A., A.D. Halvorson, J.L. Havlin, O.R. Jones, D.J. Lyon, and D.L. Tanaka. 1998. Reduced tillage and increasing cropping intensity in the Great Plains conserves soil C. Soil Tillage Res. 47:207-218. doi:10.1016/ S0167-1987(98)00107-X

Peterson, G.A., and D.G. Westfall. 2004. Managing precipitation use in sustainable agroecosystems. Ann. Appl. Biol. 144:127-138. doi:10.1111/j.1744-7348.2004.tb00326.x

Reynolds, W.D., D.E. Elrick, and E.G. Youngs. 2002. Field methods (vadose and saturated zone techniques). In: J.H. Dane and G.C. Topp, editors, Methods of soil analysis. Part 4. SSSA Book Ser. 5. SSSA, Madison, WI. p. 817-877.

Rutz, J., J. Grossman, and A. Jani. 2012. Potential contributions of legume cover crop root biomass to labile organic matter pools. Agronomy abstracts. ASA, CSSA, and SSSA Int. Annual Meet. 21-24 Oct. 2012. ASA, CSSA, and SSSA, Madison, WI. http://scisoc.confex.com/scisoc/2012am/ webprogram/Paper74884.html (accessed 11 Nov. 2012).

SAS Institute. 2012. SAS OnlineDoc 9.1.3. SAS Inst., Cary, NC. support.sas. com/onlinedoc/913/docMainpage.jsp (accessed 22 Nov. 2012).

Schlegel, A.J., and J.L. Havlin. 1997. Green fallow for the central Great Plains. Agron. J. 89:762-767. doi:10.2134/agronj1997.00021962008900050009x

Sharratt, B., and G. Feng. 2009. Windblown dust influenced by conventional and undercutter tillage within the Columbia Plateau, USA. Earth Surf. Process. Landf. 34:1323-1332. doi:10.1002/esp.1812

Shaver, T.M., G.A. Peterson, and L.A. Sherrod. 2003. Cropping intensification in dryland systems improves soil physical properties: Regression relationships. Geoderma 116:149-164. doi:10.1016/S0016-7061(03)00099-5

Sherrod, L.A., G.A. Peterson, D.G. Westfall, and L.R. Ahuja. 2003. Cropping intensity enhances soil organic carbon and nitrogen in a no-till agroecosystem. Soil Sci. Soc. Am. J. 67:1533-1543. doi:10.2136/sssaj2003.1533

Tanaka, D.L., A. Bauer, and A.L. Black. 1997. Annual legume cover crops in spring wheat-fallow systems. J. Prod. Agric. 10:251-255.

Tisdall, J.M., and J.M. Oades. 1982. Organic matter and water-stable aggregates in soils. J. Soil Sci. 62:141-163.

Unger, P.W., and M.F. Vigil. 1998. Cover crop effects on soil water relationships. J. Soil Water Conserv. 53:200-207.

Zhu, J.C., C.J. Gantzer, S.H. Anderson, E.E. Alberts, and R.R. Beuselinck. 1989. Runoff, soil and dissolved nutrient losses from no-tillage soybean and winter cover crops. Soil Sci. Soc. Am. J. 53:1210-1214. doi:10.2136/ sssaj1989.03615995005300040037x 